\title{
Cellular and Mitochondrial Effects of Folate Antagonism by Pyrimethamine in Saccharomyces cerevisiae
}

\author{
By A. B. STONE AND D. WILKIE \\ Department of Botany and Microbiology, \\ University College London, London WCI E $6 B T$
}

(Received I4 December 1973; revised 24 March I974)

\begin{abstract}
S U M MAR Y
Pyrimethamine (PY), an inhibitor of folate reductase, blocks mitochondrial protein synthesis in yeast, presumably by creating a shortage of formylmethionyltRNA. This has been established by measuring in intact cells the effect of the drug on the formation of cytochromes $a-a_{3}$ and $b$, and on the incorporation of labelled leucine when cytoplasmic protein synthesis is suppressed by cycloheximide. As a result, growth of the organism in non-fermentable (glycerol) medium is arrested by relatively low concentrations of PY, which have little effect in fermentable (dextrose) medium where respiratory activity is not essential. However, higher drug concentrations do inhibit growth in dextrose medium, probably by preventing thymine synthesis. Under some conditions the budding process is modified, giving rise to abnormal elongated cells. The inhibitory effect of PY is prevented by exogenous tetrahydrofolate.

Prolonged exposure to low concentrations of the drug, or shorter exposure to higher concentrations, leads to an induction of mitochondrial petite mutants and cell death, presumably as a consequence of thymine starvation. Petite mutants are particularly susceptible to killing by PY. Those induced by the drug are of the suppressible type, and hence would appear to result from a modification to (rather than a loss of) the mitochondrial DNA.
\end{abstract}

\section{INTRODUCTION}

Folate analogues which inhibit folate reductase block the conversion of dihydrofolate to tetrahydrofolate (THFA) and so suppress all formylation reactions involving formyl-THFA. This affects the synthesis of glycine, methionine, purines, pantothenate and thymine. It also prevents the formylation of methionyl-tRNA ${ }_{\text {met }}$, which is essential for the initiation of polypeptide synthesis in bacteria and mitochondria but not, apparently, for protein synthesis in the cytoplasm of eukaryotes (Bianchetti, Lucchini \& Sartirana, I971; Rudland \& Clark, I972). Trimethoprim, a potent inhibitor of folate reductase in bacteria, is ineffective against our yeast strains. However, we have found that pyrimethamine (PY), commonly used as an antimalarial drug and now under test as an agent against leukaemia (Geils, Scott, Baugh \& Butterworth, I97I), is a useful inhibitor in this organism and is considerably more effective than methotrexate, another folate reductase inhibitor. The potency of PY may be a consequence of its high lipophilicity, allowing easier passage across the cell membrane.

The culture media used in the present work provide a readily assimilable source of amino acids, purines and pantothenate, so that the inhibition observed can only result from a shortage of thymine or a block in mitochondrial protein synthesis. In Saccharomyces cerevisiae these two aspects are distinguishable, since mitochondrial respiratory function is necessary only when the organism is growing on non-fermentable substrate (e.g. glycerol) and not when 
a fermentable sugar (e.g. dextrose) is provided. Thus preferential inhibition of mitochondrial protein synthesis (necessary for the development of the respiratory chain) would arrest growth only in the former case.

\section{METHODS}

Organisms. Sixteen haploid strains of Saccharomyces cerevisiae were used for initial screening purposes, of which three were studied in more detail: B4I (mating type $\alpha, \mathrm{ura}^{-}$, his ${ }^{-}$); DI 8 (mating type a, met $^{-}$, arg $^{-}$); D75 (mating type a, met $^{-}$, arg $^{-}$). Candida albicans was obtained from the Wright-Fleming Institute, London.

Cultural conditions. Yeast extract ( $\% \%$ Difco) medium was supplemented with $4 \%(\mathrm{w} / \mathrm{v})$ glycerol (YEG) or $2 \%(w / v)$ dextrose (YED), solidified where required with $2 \%(w / v)$ Difco agar. Minimal medium (MM) (Mortimer \& Hawthorne, I969), containing glycerol as carbon source, was supplemented with yeast extract $(0 \cdot \mathrm{I} \%)$, uracil $(\mathrm{I} O \mu \mathrm{g} / \mathrm{ml})$ and histidine $(\mathrm{I} 0 \mu \mathrm{g} / \mathrm{ml})$. Culture temperature was $30{ }^{\circ} \mathrm{C}$. Measurement of inhibition of growth and isolation of resistant mutants was carried out as described in Wilkie (1972). Anaerobic cultures were obtained by growing cells under nitrogen in a Fildes cylinder. MM containing dextrose $(2 \%, \mathrm{w} / \mathrm{v})$ was used to select cliploids from crosses between strains B4I and D75.

Chemicals. Pyrimethamine sulphate was the gift of Dr A. H. Griffith, Wellcome Research Laboratories, Beckenham, Kent. Cycloheximide and THFA were purchased from KochLight Laboratories, and erythromycin, methotrexate and trimethoprim from Abbot Laboratories, Lederle Laboratories and Burroughs, Wellcome and Co., respectively.

Cytochrome absorption spectra. Cells from $200 \mathrm{ml}$ cultures were washed twice with $1 \%$ saline, suspended in distilled water and the absorbance measured at room temperature in the Unicam SP I800 recording spectrophotometer.

Measurement of respiratory activity. Washed cells from $3 \mathrm{ml}$ culture were resuspended at approximately $\mathrm{I}^{6}$ cells $/ \mathrm{ml}$ in sodium phosphate buffer $(0.1 \mathrm{mM}, \mathrm{pH} 6.8)$ containing sodium succinate $(0.5 \mathrm{~mm})$. Oxygen uptake was measured polarographically in a Clark-type oxygen electrode coupled to a pen recorder.

Growth curves. Extinctions (corrected for non-linear response) were measured either with an E.E.L. colorimeter (Evans Electroselenium Ltd) using filter OGR I (Fig. I) or with a Hilger colorimeter at $580 \mathrm{~nm}$ (Fig. 2).

Protein synthesis determination. Portions ( $\mathrm{I} \mathrm{ml}$ ) of cultures growing exponentially in supplemented $\mathrm{MM}$ (see above) were inoculated into glass centrifuge tubes containing $3 \mu \mathrm{g} \mathrm{L}-\left[4,5^{-3} \mathrm{H}\right]$ leucine $\left(30 \mathrm{Ci} / \mathrm{mm}\right.$ ) and shaken at $30{ }^{\circ} \mathrm{C}$ for $1.5 \mathrm{~h}$, after which incorporation was stopped by the addition of $2 \mathrm{ml}$ trichloroacetic acid $(5 \%, \mathrm{w} / \mathrm{v})$. Unlabelled yeast cells were added to increase bulk, cells spun down, resuspended in the acid, spun down again and transferred to a Whatmann GFC glass-fibre filter (diam. $24 \mathrm{~mm}$ ). The filter was washed with trichloroacetic acid $(5 \%, \mathrm{w} / \mathrm{v})$, then with ethanol and dried. Radioactivity was determined in a Packard Tricarb liquid scintillation counter with toluene/butyl-PBD scintillant.

Staining of cell nuclei. Giemsa staining was used according to the method of Ramirez \& Miller (1962).

\section{RESULTS}

\section{Inhibition by $P Y$ on solid media}

Initial screening for drug activity against 16 yeast strains was performed on agar plates containing non-fermentable YEG or fermentable YED media. On YEG, all strains tested were totally inhibited in growth at a drug concentration of $700 \mu \mathrm{g} / \mathrm{ml}$. At $250 \mu \mathrm{g} / \mathrm{ml}$, eight strains were inhibited, while $100 \mu \mathrm{g} / \mathrm{ml}$ arrested the growth of two strains (B4I and DI8). On 
YED, on the other hand, $1000 \mu \mathrm{gPY} / \mathrm{ml}$ inhibited all strains, and six strains were inhibited at $700 \mu \mathrm{g} / \mathrm{ml}$. On dextrose medium, $250 \mu \mathrm{g} / \mathrm{ml}$ had no detectable effect on any of the strains. These results suggest that low concentrations of PY selectively suppress protein synthesis in the mitochondria. Inhibition of growth on YED medium at higher drug concentrations presumably results from thymine starvation, which would appear to require a more complete suppression of THFA synthesis.

Cytoplasmic petite mutants, in which there is no mitochondrial protein synthesis (see Borst, 1972), were also inhibited by PY on YED medium and this is discussed in detail later.

Trimethoprim at a concentration of $1000 \mu \mathrm{g} / \mathrm{ml}$ had no effect on the growth of the 16 strains on either YEG or YED medium. Methotrexate was inhibitory but was less potent than PY. Only half of the strains were inhibited at $1000 \mu \mathrm{g}$ of this drug/ml on YEG medium, but some growth was possible by these strains at this concentration on YED medium. At a methotrexate concentration of $250 \mu \mathrm{g} / \mathrm{ml}$, no inhibitory effect on growth was detectable on either medium.

Sulphanilamide and sulphathiazole, compounds which in bacteria inhibit folate biosynthesis (rather than folate reduction), had no apparent effect on growth of the yeast strains at concentrations up to $1000 \mu \mathrm{g} / \mathrm{ml}$.

\section{Inhibition on fermentable substrates other than dextrose}

Strains were also grown on solid medium with galactose or melibiose as the carbon source. In general, the cultures were more susceptible to inhibition by PY than they were on dextrose medium, but less so than on glycerol medium. Thus, a differential effect was still seen in comparing fermentable with non-fermentable medium when using fermentable sugars other than dextrose. However, the results suggest that some degree of mitochondrial function is necessary for the utilization of galactose and melibiose. This is supported by the finding that when mitochondrial protein synthesis was arrested by the addition of $1000 \mu \mathrm{g}$ erythromycin $/ \mathrm{ml}$, growth of all $\mathrm{I} 6$ strains was inhibited on YEG medium and of ten strains on medium containing galactose or melibiose. Since erythromycin is a specific inhibitor of mitochondrial protein synthesis (see Wilkie, 1970), there was no inhibition on YED medium, as expected. Furthermore, two out of three cytoplasmic petite strains tested failed to grow on melibiose or galactose medium. It is possible that in some strains defects in the mitochondria, resulting either from the petite $\left(\rho^{-}\right)$mutation or from the inhibitory effects of drugs, limit the uptake of melibiose and galactose by the cells. The observation that growth in YED medium in the presence of PY $(100 \mu \mathrm{g} / \mathrm{ml})$ greatly reduces the flocculent character of strain B4I also implicates a change at the cell surface. An apparently similar situation is described by Linstead, Evans \& Wilkie (1974), in which the cell binding of the lipophilic drug imipramine is frequently altered on conversion of yeast strains to the petite condition.

\section{Effect of $P Y$ on growth rate}

Since B4I was the most sensitive strain on solid medium it was studied in more detail. Growth curves obtained with various concentrations of the drug are shown in Fig. 1. This again illustrates the greater sensitivity of the organism in non-fermentable medium.

When THFA $(1000 \mu \mathrm{g} / \mathrm{ml})$ was added to the drug medium, the inhibitory effect was prevented and growth proceeded more or less normally (Fig. 2). This indicates that folate reductase is the only significant site at which PY acts, and excludes the possibility of the drug acting as an uncoupler of oxidative phosphorylation or interfering with the metabolism of other pteridine compounds. 

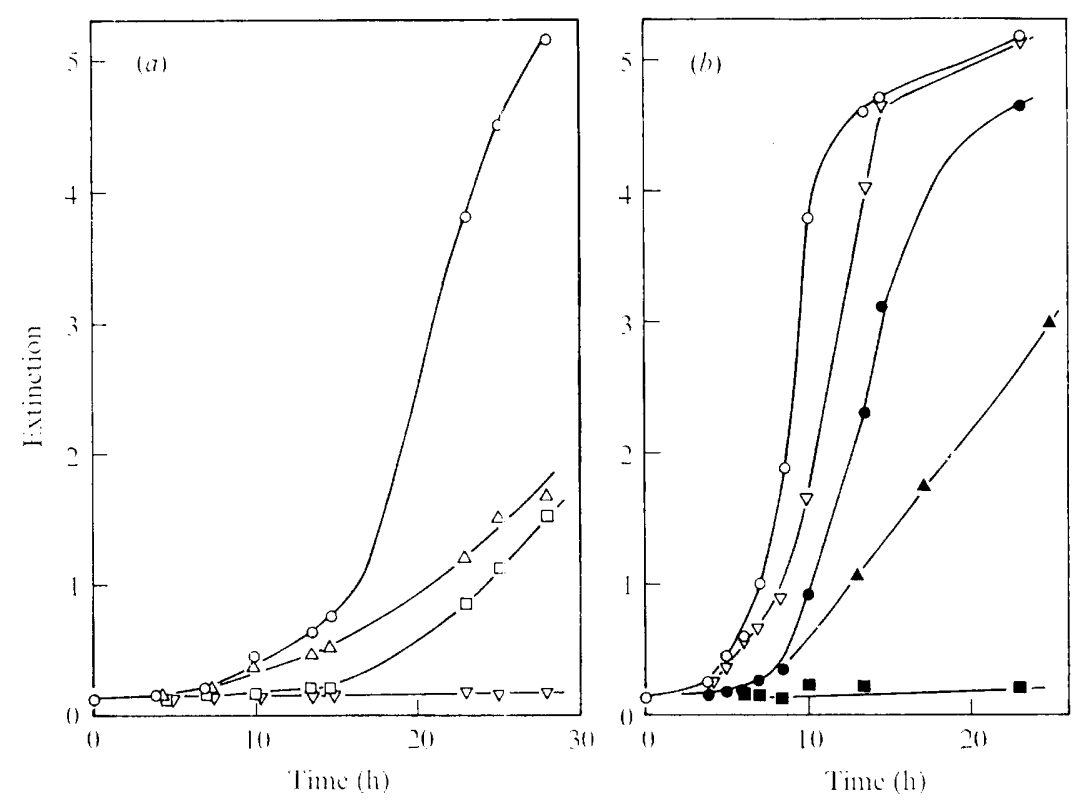

Fig. I. Effect of PY on the growth rate of strain B4I grown on (a) YEG medium, $(b)$ YED medium. $O$, Control; PY at: $\Delta, 20 \mu \mathrm{g} / \mathrm{ml} ; \square, 50 \mu \mathrm{g} / \mathrm{ml} ; \nabla, \mathrm{I} 20 \mu \mathrm{g} / \mathrm{ml} ; \boldsymbol{\bullet}, 300 \mu \mathrm{g} / \mathrm{ml} ; \boldsymbol{\Delta}, 600 \mu \mathrm{g} / \mathrm{ml} ; \mathbf{\square}$, $\mathrm{I} 000 \mu \mathrm{g} / \mathrm{ml}$.

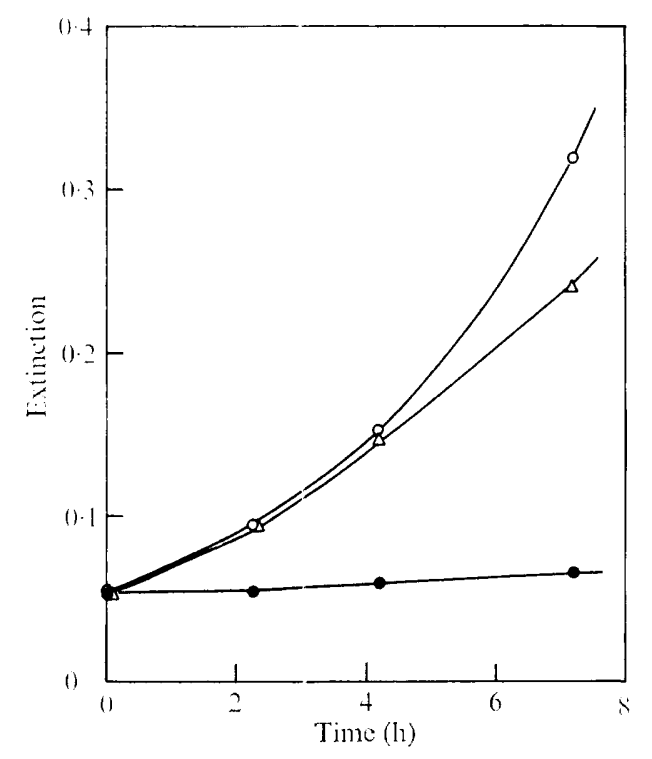

Fig. 2. Effect of tetrahydrofolate on the inhibition of strain B4 I by PY (YEG medium). O, Control; $\bullet$ PY $(250 \mu \mathrm{g} / \mathrm{ml}) ; \triangle$, PY $(250 \mu \mathrm{g} / \mathrm{ml})+$ THFA $(1000 \mu \mathrm{g} / \mathrm{ml})$. 

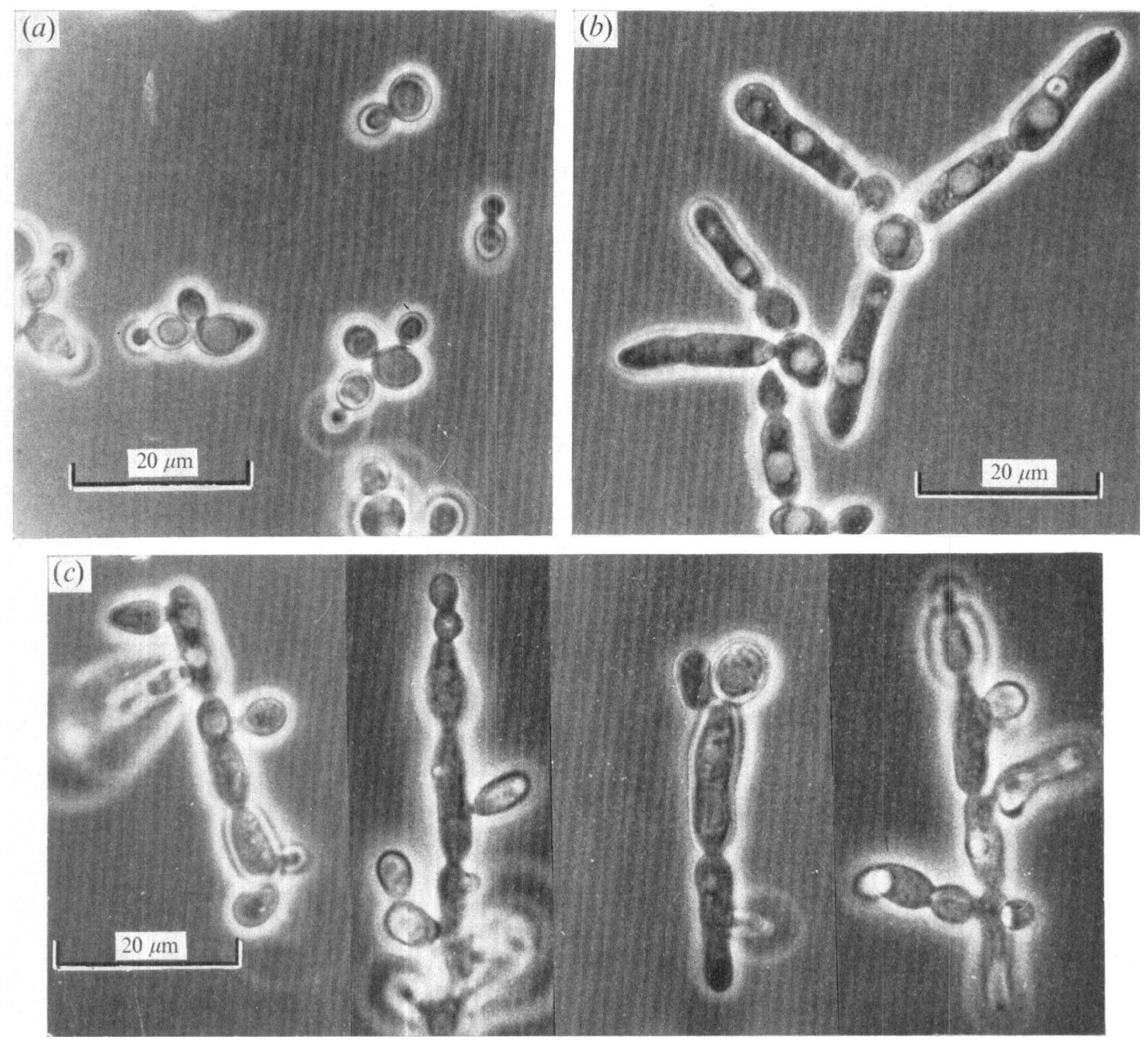

Fig. 3. Effect of PY on the morphology of strain B4 I $(a)$ grown on YEG; $(b)$ grown for $\mathrm{I} 6 \mathrm{~h}$ on YEG + PY $(100 / \mathrm{g} / \mathrm{ml}) ;(c)$ grown for $16 \mathrm{~h}$ on YEG + PY $(100 \mu \mathrm{g} / \mathrm{ml})$, then $2.5 \mathrm{~h}$ on drug-free YEG.

\section{Effect of $P Y$ on cell morphology}

When strain B4 I was grown in YEG medium containing 50 to $100 \mu \mathrm{g} \mathrm{PY} / \mathrm{ml}$, normal budding of the yeast was suppressed. After about $\mathrm{I} 6 \mathrm{~h}$ incubation, individual cells gave rise to small clumps of elongated cells (Fig. $3 a, b$ ). After staining with Giemsa, it was apparent that all cells possessed a nucleus and that many were binucleate. On incubation in drug-free YEG, each elongated cell proceeded to bud (Fig. $3 c$ ). When elongated cells were isolated by micromanipulation onto drug-free YEG and YED agar media, they recovered inasmuch as they produced normal $\rho^{+}$buds after 2 to $4 \mathrm{~h}$. The parent cells retained their elongated form, however.

If THFA ( $1000 \mu \mathrm{g} / \mathrm{ml}$ ) was present in the YEG medium containing $100 \mu \mathrm{g} \mathrm{PY} / \mathrm{ml}$, no cell elongation occurred.

Cells of B4I neither budded nor elongated on YEG medium containing a higher con- 
Table I. The effect of $P Y$ on respiratory activity, viability and the frequency of the $\rho^{--}$mutation in strain $\mathrm{B} 4 \mathrm{I}$ of S. cerevisiae

\begin{tabular}{|c|c|c|c|c|c|c|c|c|c|c|c|c|c|c|c|c|}
\hline \multirow{3}{*}{$\begin{array}{l}\text { Time of treatment }(\mathrm{h}) \ldots \\
\text { Pyrimethamine }(\mu \mathrm{g} / \mathrm{ml}) .\end{array}$} & \multicolumn{10}{|c|}{ YEG } & \multicolumn{6}{|c|}{ YED } \\
\hline & $1 \cdot 5$ & 3 & 3 & $\varepsilon$ & 2 I & 24 & 24 & 27 & 40 & 47 & 3 & 3 & 24 & 24 & 48 & 48 \\
\hline & 160 & 100 & 1000 & 160 & 160 & 100 & 1000 & 120 & 75 & I 20 & 100 & 1000 & 100 & 1000 & 300 & 1000 \\
\hline $\begin{array}{l}\text { Respiratory activity ( } \% \text { of } \\
\text { control at zero time) }\end{array}$ & 100 & & & 50 & 0 & & 0 & 100 & 0 & o & & & & & & \\
\hline Viable cells $(\%)$ & 100 & 100 & I 3 & 100 & 37 & 100 & 0 & 100 & & 5 & 100 & 70 & 100 & 16 & & \\
\hline$\rho^{-}$Among survivors $(\%)$ & 2 & 5 & 22 & 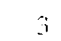 & I & 5 & & 5 & & 30 & 5 & 15 & 5 & 36 & 27 & 78 \\
\hline
\end{tabular}

centration of PY $(500 \mu \mathrm{g} / \mathrm{ml})$. In YED inedium, PY did not affect the shape of B4I cells at any concentration tested ( 50 to $1000 \mu \mathrm{g} / \mathrm{ml}$ ).

Cells of strain DI 8 behaved somewhat differently from those of B4I. In YEG containing I00 $\mu \mathrm{g} \mathrm{PY} / \mathrm{ml}$, cell volume increased 10 to 20 -fold with only slight elongation.

The fact that elongated cells were abie to produce normal buds on transfer to drug-free medium, both YEG and YED, indicated that any abnormalities in the mitochondria or in the nuclei were reversible and that only the shape of the cell envelope was permanently altered. The basis of the phenomenon is not clear. It is not due to blockage of the mitochondrial system alone, since erythromycin failed to induce elongated forms of B4I. Nor can a shortage of thymine alone explain elongation, as no such effect was observed on YED medium at any concentration of PY.

It is of interest that daunomycin, which preferentially inhibits mitochondrial RNA synthesis in S. cerevisiae (Evans, Linstead, Rhodes \& Wilkie, I973), also produces elongated cells, as does tannic acid, a potent inhibitor of mitochondrial function in this organism (D. Linstead and D. Wilkie, unpublished observations).

\section{Inhibition of respiratory activity, loss of viability and induction of the petite mutation by $P Y$}

The background frequency of $\rho^{-}$cells is about $5 \%$ in strain B4I and $2 \%$ in DI 8 . These frequencies were increased significantly in the presence of PY on either carbon source, but only at high concentrations of the druis or long exposure to low concentrations. That is, petite mutants appeared under conditicns which had a pronounced lethal effect (Table I). Petite induction was always accompanied by impaired oxygen uptake in the treated culture, although, on the other hand, reduced respiratory activity was not always accompanied either by killing or the appearance of $\rho^{-}$cells (Table $\mathrm{I}$ ). That there was indeed induction of petites, rather than selection by PY, was substantiated by testing the PY sensitivity of both spontaneous and 'PY-induced' $\rho^{-}$strains derived from B4I. These mutants were found to be no more resistant than the parent strain. On the contrary, the $\rho^{-}$strains were more sensitive to the drug. Using spot inocula (Wilkie, 972) on to YED agar, growth of all petite strains tested was seriously inhibited at a concentration of $100 \mu \mathrm{g} \mathrm{PY} / \mathrm{ml}$ and totally arrested at $300 \mu \mathrm{g} / \mathrm{ml}$. Growth of the $\rho^{+}$parent strain was only slightly affected at $300 \mu \mathrm{g} / \mathrm{ml}$, and $600 \mu \mathrm{g} / \mathrm{ml}$ was required for total inhibition.

Since there is no protein synthesis in petite mitochondria (see Borst, 1972), inhibition of growth in the respiratory mutants is probably due to thymine deficiency. A further feature of petite strains was that they rapidly died when exposed to PY even at moderately low concentrations (Fig. 4). These findings again point to the involvement of the mitochondria in the 


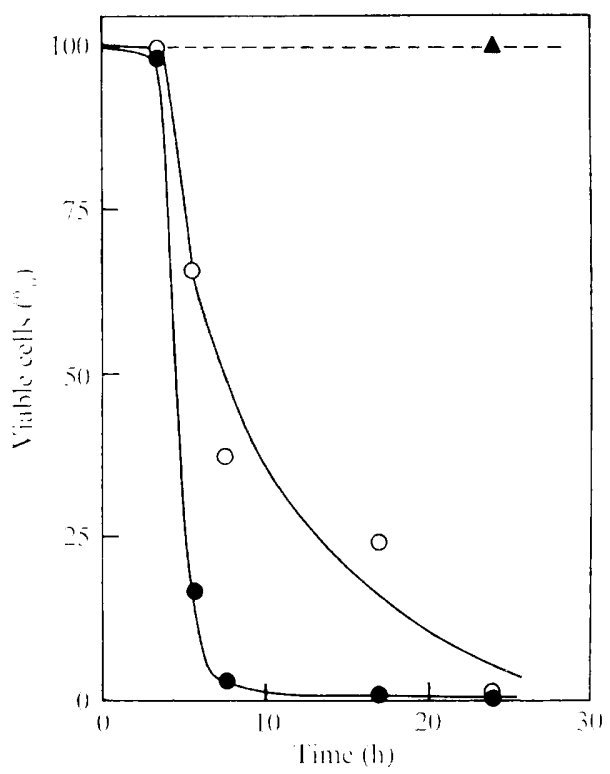

Fig. 4. Loss of viability of a PY-induced petite mutant of strain B4I during incubation in YEG $(O)$, or YEG containing PY at $120 \mu \mathrm{g} / \mathrm{ml}(\bullet)$; the relative insensitivity of the parental strain in YEG + PY $(\mathrm{I} 20 \mu \mathrm{g} / \mathrm{ml})$ is also shown $(\boldsymbol{\Delta})$.

specification of cell membrane components controlling permeability (cf. above, and Linstead et al. 1974), alterations which may permit a greater intracellular concentration of the drug.

\section{Suppressivity of $P Y$-induced petite strains}

Eight $\rho^{-}$strains were obtained from a B4I culture which had been treated for $24 \mathrm{~h}$ with $1000 \mu \mathrm{g} \mathrm{PY} / \mathrm{ml}$ in YED. Each of these was crossed with strain D75 and individual diploids obtained. The frequencies of $\rho^{-}$cells amongst the diploid cultures were I, I, 2, 3, 3, 8, I 7 and $33 \%$ respectively. These figures are significantly different from those obtained from the control cross of B4I by D75 $\left(\rho^{+} \times \rho^{+}\right)$, where the frequency of $\rho^{-}$cells was about $0.2 \%$ in the derived diploid culture. Hence, PY produces suppressive petites, suggesting that they result from a modification of mitochondrial DNA rather than the loss of this molecule, at least in the cases tested (see Borst, 1972).

\section{PY-resistant mutants}

A lawn of B4I was spread on YEG plates containing $100 \mu \mathrm{g} \mathrm{PY} / \mathrm{ml}$. After $48 \mathrm{~h}$, several colonies developed against a background of inhibited cells. Thirteen of these spontaneous PY-resistant mutants were tested on YEG and YED plates containing PY at various concentrations (Table 2), using very dilute inocula. On YEG, all were able to make substantial growth at $100 \mu \mathrm{g} \mathrm{PY} / \mathrm{ml}$; some were totally inhibited at $300 \mu \mathrm{g} / \mathrm{ml}$, whereas others continued to grow at this higher concentration of the drug. On YED medium, all were more resistant than the parent strain, but again there was considerable variation in this respect. Some of these resistant mutants could have reduced permeability to the drug or the ability to detoxify it, and others a modified folate reductase. Further genetic and biochemical analyses will be required to establish these points. 
Table 2. PY tolerance of spontaneous resistant mutants (R) of strain B4 I of S. cerevisiae isolated from $Y E G$ plates containing $P Y(\mathrm{I} 00 \mu \mathrm{g} / \mathrm{ml})$

\begin{tabular}{|c|c|c|c|c|c|c|c|c|c|}
\hline \multirow[b]{2}{*}{ PY concentration $(\mu \mathrm{g} / \mathrm{ml})$} & \multicolumn{4}{|c|}{ YEG } & \multicolumn{5}{|c|}{ YED } \\
\hline & 0 & 100 & 300 & 500 & 0 & 100 & 300 & 500 & 800 \\
\hline B4I parent & 3 & 0 & o & 0 & 3 & 3 & I & 0 & 0 \\
\hline R I & 3 & 2 & 1 & 0 & 3 & 3 & 2 & 0 & 0 \\
\hline R2 & 3 & 2 & 1 & 0 & 3 & 3 & 2 & I & 0 \\
\hline R3 & 3 & 2 & 0 & 0 & 3 & 3 & 2 & I & o \\
\hline R4 & 3 & 2 & I & 0 & 3 & 3 & 2 & o & o \\
\hline R5 & 3 & 2 & I & 0 & 3 & 3 & 2 & 1 & 0 \\
\hline R6 & 3 & 2 & 2 & 0 & 3 & 3 & 2 & I & 0 \\
\hline R7 & 3 & 2 & I & 0 & 3 & 3 & 2 & 0 & 0 \\
\hline $\mathrm{R} 8$ & 3 & 2 & I & 0 & 3 & 3 & 2 & 0 & 0 \\
\hline R9 & 3 & 2 & 1 & 0 & 3 & 3 & 2 & 0 & 0 \\
\hline RIO & 3 & 2 & 0 & 0 & 3 & 3 & 2 & 0 & 0 \\
\hline RII & 3 & 2 & 0 & 0 & 3 & 3 & 2 & 0 & 0 \\
\hline R I 2 & 3 & 2 & 0 & 0 & 3 & 3 & 2 & 0 & 0 \\
\hline $\mathrm{RI} 3$ & 3 & 2 & 2 & 0 & 3 & 3 & 2 & 0 & 0 \\
\hline
\end{tabular}

$\circ, \mathrm{I}, 2,3$, Arbitrary units of growth, from no growth to full growth.

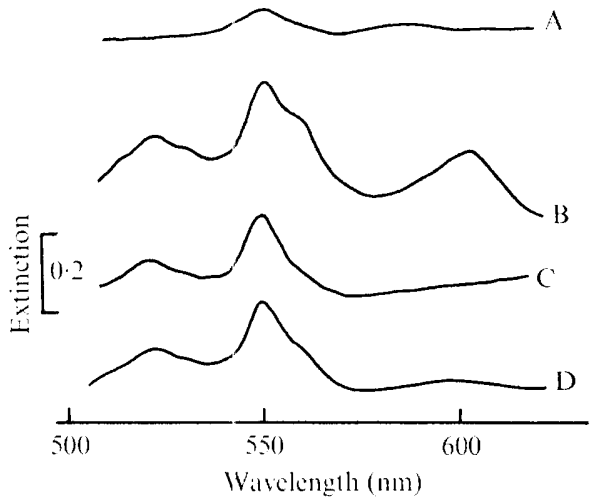

Fig. 5. Absorption spectra of strain $\mathrm{B} 4 \mathrm{I}$, grown anaerobically in YED medium, during aerobic recovery in YEG medium +0.2\% glucose. (A) Anaerobic; (B) aerobic control; (C) aerobic + erythromycin $(1000 \mu \mathrm{g} / \mathrm{ml}) ;(D)$ aerobic $+\mathrm{PY}(160 \mu \mathrm{g} / \mathrm{ml})$. The absorption maxima of cytochromes $c, b$, and $a-a_{3}$ are respectively 550,562 and $605 \mathrm{~nm}$; absorption at $585 \mathrm{~nm}$ represents a precursor of cytochrome $a-a_{3}$.

Inhibition of synthesis of cytochromes $a-a_{3}$ and $b$ by $P Y$

The addition of PY up to a concentration of $600 \mu \mathrm{g} / \mathrm{ml}$ to cells of strain B4I in the oxygen electrode had no detectable effect on the oxygen uptake of these cells. This indicates that the inhibitory effect of PY on YEG medium does not result from a direct effect on the function of mitochondria, but presumably from interference with their biogenesis. Comparison of cytochrome spectra provides a useful means of assessing mitochondrial protein synthesis in intact cells, since cytochrome $c$ is made in the cytoplasm, whereas it is well established that the formation of cytochromes $a-a_{3}$ and $b$ requires protein synthesis in the mitochondria (cf. Wilkie, 1970). That PY prevents the synthesis of the latter cytochromes was apparent from a comparison of treated and untreated cells (Fig. 5). In this series of experiments, anaerobically grown cells of strain B4I were used in which cytochrome synthesis in general was severely suppressed (Fig. 5A). When these cells were transferred to aerobic conditions in YEG 
Table 3. Effect of erythromycin, cycloheximide and $P Y$ on the incorporation of $\left[{ }^{3} \mathrm{H}\right]$ leucine by strain $\mathrm{B} 4 \mathrm{I}$ of $S$. cerevisiae growing in minimal medium

\begin{tabular}{|c|c|c|}
\hline & Conditions & $\begin{array}{l}\text { C.p.m. } / \mathrm{ml} \\
\text { (incorporated in } \mathrm{I} \cdot 5 \mathrm{~h} \text { ) }\end{array}$ \\
\hline \multirow[t]{6}{*}{ Expt I } & Control & 34300 \\
\hline & Erythromycin $(1000 \mu \mathrm{g} / \mathrm{ml})$ & 24600 \\
\hline & PY ( I $20 \mu \mathrm{g} / \mathrm{ml})$ & 25500 \\
\hline & Cycloheximide $(30 \mu \mathrm{g} / \mathrm{ml})$ & $5 \mathrm{I} 3$ \\
\hline & + erythromycin $(1000 \mu \mathrm{g} / \mathrm{ml})$ & I 86 \\
\hline & $+\mathrm{PY}(120 \mu \mathrm{g} / \mathrm{ml})$ & 184 \\
\hline \multirow[t]{8}{*}{ Expt II } & Control & 88700 \\
\hline & Erythromycin $(1000 \mu \mathrm{g} / \mathrm{ml})$ & 9 I 900 \\
\hline & $\mathrm{PY}(130 \mu \mathrm{g} / \mathrm{ml})$ & 73200 \\
\hline & PY $(170 \mu \mathrm{g} / \mathrm{ml})$ & 71500 \\
\hline & Cycloheximide $(20 \mu \mathrm{g} / \mathrm{ml})$ & 1602 \\
\hline & + erythromycin $(1000 \mu \mathrm{g} / \mathrm{ml})$ & 600 \\
\hline & + PY $(130 \mu \mathrm{g} / \mathrm{ml})$ & 982 \\
\hline & $+P Y(170 \mu \mathrm{g} / \mathrm{ml})$ & 690 \\
\hline
\end{tabular}

liquid medium supplemented with $0.2 \%$ dextrose, synthesis of all cytochromes occurred (Fig. 5B). When erythromycin ( $1000 \mu \mathrm{g} / \mathrm{ml}$ ) was present during this period, only cytochrome $c$ appeared (Fig. 5 C). PY (I $60 \mu \mathrm{g} / \mathrm{ml}$ ) had a similar effect (Fig. $5 \mathrm{D}$ ), except that the appearance of cytochromes $a-a_{3}$ and $b$ was not entirely prevented, presumably because of the cells' ability to draw on a pre-existing pool of formyl-THFA.

\section{Inhibition of $\left[{ }^{3} \mathrm{H}\right]$ leucine incorporation into mitochondria by $P Y$}

The view that PY inhibits mitochondrial protein synthesis was confirmed by measuring incorporation of radioactive leucine by a culture of B4I in which cytoplasmic protein synthesis was suppressed by cycloheximide. The cycloheximide-insensitive incorporation was significantly reduced when low concentrations of PY were present (Table 3). Erythromycin had essentially the same effect.

\section{Inhibition of Candida albicans by $P Y$}

The sensitivity of $S$. cerevisiae to PY, and the fact that tolerance limits to PY in humans are well known, suggested that the drug may be potentially useful in the treatment of human mycosis. The drug was therefore tested against Candida albicans, a common human pathogen, for growth inhibition in YEG medium and in a Casamino-acids $(3 \% \mathrm{w} / \mathrm{v})$ medium containing dextrose $(0.2 \%)$. In both of these media, growth of the organism was completely arrested by PY at a concentration of $500 \mu \mathrm{g} / \mathrm{ml}$, and was $50 \%$ inhibited at $250 \mu \mathrm{g} / \mathrm{ml}$. The finding that sensitivity to the drug is independent of the carbon source is to be expected, since $C$. albicans is an obligate aerobe requiring functional mitochondria even for growth in dextrose medium. As serum levels of PY following administration of the drug are generally in the region of I to $\mathrm{I} \cdot 5 \mu \mathrm{g} / \mathrm{ml}$ (Geils et al. $\mathrm{r} 97 \mathrm{I}$ ), its usefulness in cases of Candida mycosis is doubtful. 


\section{DISCUSSION}

Our results support the view that the inhibition of yeast growth by high concentrations of $\mathrm{PY}$ is a consequence of thymine starvation. At lower concentrations, the main effect of the drug is to suppress protein synthesis in mitochondria, confirming that $\mathrm{N}$-formylmethionine is indispensable for the initiation of mitochondrial proteins. Under the latter conditions, any available formyl groups are preferentially used for thymine synthesis. This is analogous to the situation in trimethoprim-inhibited Escherichia coli, where, indeed, a standard technique for the isolation of thymineless mutants exploits the competition between DNA synthesis and protein synthesis for the small amount of formyl-THFA present (Stacey \& Simson, 1965).

At low concentrations of PY on glycerol medium, the inhibitory effects are initially reversible, as seen when the drug is removed from elongated cells. At high concentrations, or with continued exposure of the cells to low concentrations, there is an induction of the petite condition and a loss of viability. We suggest that both these effects result from thymine starvation following more complete inhibition of THFA synthesis. Petite induction could result from a blockage of mitochondrial protein synthesis alone (Williamson, Maroudas \& Wilkie, 1971), but in this respect it is significant that inhibition of mitochondrial protein synthesis by erythromycin, under the same experimental conditions as used for PY, had no effect either on viability or on the frequency of the petite mutation. A detailed study of the PY-resistant mutants, and of mutants that can assimilate exogenous dTMP, should provide answers to these problems.

After this work was completed, a paper was published by Wintersberger \& Hirsch (1973) in which they report that methotrexate at concentrations of I $\mathrm{mm}(432 \mu \mathrm{g} / \mathrm{ml})$ and upwards can reduce the growth of some strains of Saccharomyces cerevisiae and S. carlsbergensis, and can induce the petite condition, when cells are utilizing fermentable substrates.

This work was supported in part by the Medical Research Council. We thank Dr A. H. Griffith (Wellcome Research Laboratories) for supplying PY, Dr R. Davies (WrightFleming Institute) for performing the tests on C. albicans, and Mrs S. Mahadevaiah and Mrs D. Collier for able technical assistance.

\section{REFERENCES}

Bianchetti, R., Lucchini, G. \& Sartirana, M. L. (197I). Endogenous synthesis of formyl-methionine peptides in isolated mitochondria and chloroplasts. Biochemical and Biophysical Research Communications 42, 97-IO2.

Borst, P. (1972). Mitochondrial nucleic acids. Annual Reviews of Biochemistry 4r, 333-376.

Evans, I. H., Linstead, D., Rhodes, P. M. \& Wilkie, D. (I973). Inhibition of RNA synthesis in mitochondria by daunomycin. Biochimica et biophysica acta 312, 323-336.

Geils, G. F., Scott, C. W., Jun., Baugh, C. M. \& Butterworth, C. E., Jun. (I97I). Treatment of meningeal leukemia with pyrimethamine. Blood 38, 13 I-1 37.

Linstead, D., Evans, I. H. \& Wrukie, D. (I974). Mitochondrial genetic factors in the cellular response to chlorimipramine in Saccharomyces cerevisiae. In The Biogenesis of Mitochondria, pp. 179-193. Edited by A. M.' Kroon and C. Saccone. New York and London: Academic Press.

Mortimer, R. K. \& Hawthorne, D. C. (I969). Yeast genetics. In The Yeasts, vol. I, pp. 385-460. Edited by A. H. Rose and J. S. Harrison. London: Academic Press.

Ramirez, C. \& Miller, J. J. (1962). Observations on vegetative nuclear division in Saccharomyces cerevisiae. Canadian Journal of Microbiology 8, 603-6io7.

Rudland, P. S. \& Clark, B. F. C. (1972). Polypeptide chain initiation and the role of methionine tRNA. In The Mechanism of Protein Synthesis and its Regulation, pp. 55-86. Edited by L. Bosch. London and Amsterdam: North Holland Publishing. 
Stacey, K. A. \& Simson, E. (1965). Improved method for the isolation of thymine-requiring mutants of Escherichia coli. Journal of Bacteriology 9o, 554-555.

WILKIE, D. (I970). Analysis of mitochondrial drug resistance in Saccharomyces cerevisiae. Symposia of the Society for Experimental Biology 24, 7 I--83.

WILKIE, D. (1972). The yeast cell in the antimitochondrial activity of drugs. Medical and Biological Illustration 22, I I9-I 24.

Williamson, D. H., Maroudas, N. \& Wilkie, D. (I971). Induction of the cytoplasmic petite mutation in Saccharomyces cerevisiae by antibacterial antibiotics. Molecular and General Genetics III, 209-223.

WINTERSBERGER, U. \& HirSCH, J. (I973). Induction of cytoplasmic respiratory deficient mutants in yeast by the folic acid analogue, methotrexate. I. Studies on the mechanism of petite induction. Molecular and General Genetics 126, 6I-70. 